\title{
The effectiveness of Vietnamese policies response to climate change through ARDL analysis
}

\author{
Le Hoang Nghiem ${ }^{1}$, Dang Bac Hai ${ }^{1,2}$, Tran Thi Diem Nga ${ }^{1}$, Su Thi Oanh Hoa ${ }^{1 *}$ \\ ${ }^{1}$ University of Natural Resources and Environment, Ho Chi Minh City, Vietnam \\ ${ }^{2}$ Ho Chi Minh City Open University, Vietnam \\ *Corresponding author: stohoa@hcmunre.edu.vn
}

\begin{abstract}
ARTICLE INFO
ABSTRACT

DOI: $10.46223 /$ HCMCOUJS. econ.en.11.2.1435.2021

Being a highly vulnerable country due to climate change, Vietnam has issued various climate policies while trying to keep the pace of economic growth. The study evaluates the effectiveness of these policies by examining the effect of economic and energy factors in the efforts of controlling $\mathrm{CO}_{2}$ emissions.

Received: February 02 ${ }^{\text {nd }}, 2021$

Revised: March $18^{\text {th }}, 2021$

Accepted: April 01 ${ }^{\text {st }}, 2021$

Keywords:

climate change; economic factors; energy consumption

Approach by Autoregressive Distributed Lag (ARDL) analysis, the model of a linear regression between $\mathrm{CO}_{2}$ emissions and Gross Domestic Product (GDP), Foreign Direct Investment (FDI) \& sources of energy consumption has been developed from 1985 to 2018. The study indicates that the economic factor as Foreign Direct Investment (FDI) is a possible significant element to mitigate the emission. In addition, sources of energy consumption have the important role of controlling $\mathrm{CO}_{2}$ emissions. In the long run, the consumption of non - renewable energy is a positive and significant effect on $\mathrm{CO}_{2}$ emissions while renewable energy is vice versa. These outcomes show the Foreign Direct Investment (FDI) and renewable energy consumption factors lead to the decrease of $\mathrm{CO}_{2}$ emissions in the long run for Vietnam, which implies the coexist of economic growth and decarbonization.
\end{abstract}

\section{Introduction}

After years to years of relative stability, due to the full span of human civilization, the Earth's climate is changing (Woetzel et al., 2020). The increase of average global temperature has driven infrequently extreme weather events and rising sea levels, translating into socioeconomic loss and damage. The continuous increase amount of $\mathrm{CO}_{2}$ emission in the atmosphere is the main cause of climate change. Along the same lines, Vietnam has achieved remarkable economic development since the reform in 1986, which has resulted in impressive wealth as well as vast amounts of pollutants in the environment. The amount of $\mathrm{CO}_{2}$ emission is fast growing in Vietnam and its carbon intensity is almost triple the world average (Audinet et al., 2016).

To be a highly vulnerable country, up to date, Vietnam has already engaged in many international climate change negotiations and put climate change issues on the national agenda since the 1990s. The Vietnamese government has announced and implemented a variety of national and regional climate policies. The nation has shown its active role in the battle of fighting climate change by shifting policies from solely relying on aboard funding to take responsibility for $\mathrm{CO}_{2}$ mitigation (Zimmer, Jakob, \& Steckel, 2015). Especially, in 2012, 
Vietnam issued the national Green Growth Strategy (VGGS) aiming to restructure the economy to achieve low carbon growth, which are focusing three critical strategic directions as reducing green gas emission by the energy sector, greening production in both manufactory and agriculture, and greening lifestyle and consumption (Prime Minister, 2012). The VGGS committed to reduce a GHG intensity target by national sources and international support. It has requested all line ministries, state agencies, and regional authorities to develop an action plan to meet the targets (Nguyen, 2014).

Vietnam has made some achievements (VPCP, 2019) in response to climate change; however, the overall evaluation of the effectiveness of the policies is still missing. The purpose of this study is to fill the gap by using ARDL analysis between $\mathrm{CO}_{2}$ emissions and economic factors to show whether the decoupling of environment and economy exists in Vietnam when the nation is on the pathway of pursuing a green economy.

\section{Literature review}

There is clear evidence that economic growth usually leads to environmental degradation (Beckerman, 1992), especially in developing countries. However, from a sustainable development approach, we could have achieved both economic growth and ecological sustainability. Based on the empirical phenomenon of Kuznets (1955), the economists have assumed that economic growth, rather than being a threat to the environment, would be the means to eventual environmental improvement (World Bank, 1993). The Environmental Kuznets Curve (EKC) is an inverted U-shaped between environmental quality and income per capita. In the early stages of economic growth, environmental degradation and pollution increase, but beyond some level of income per capita, the trend reverses. At high-income levels, the more economy grows, the better environmental quality is (Stern, 2004). However, many authors cautioned the mixed results varying in the function of the country and period considered (Apergis, 2016; Iwata, Okada, \& Samreth, 2012; Nasir \& Ur Rehman, 2011; Shahbaz, Haouas, \& Hoang, 2019). Many authors point out that the existence of the EKC curve is mainly in uppermiddle-income and high-income countries (Ozturk \& Acaravci, 2013; Saboori, Sapri, \& bin Baba, 2014; Shahbaz et al., 2019).

According to empirical studies of Shafik and Bandyopadhya (1992), they explained the phenomenon by the social choices about levels of environmental quality at different income levels. The World development report (World Bank, 1993, pp. 38-39) stated that "the view that greater economic activity inevitably hurts the environment is based on static assumption about technology, tastes, and environmental investment [...] and as incomes rise, the demand for improvements in environmental quality will increase, as well the resources available for investment." The pathway for developing countries to sustainable development is to pursue a green economy (UNEP, 2011).

The relationship between $\mathrm{CO}_{2}$ emission and economic factors as GDP and FDI has been studied for years. In general, in the linear regression, GDP often leads to increase $\mathrm{CO}_{2}$ emission and the researchers often test the Kuznets curve by quadratic regression and give the mixed results of the validity of EKC. Some countries display an inverted U-shape relation between pollutant emission and income while non-existence (Dinda \& Coondoo, 2006; Mrabet \& Alsamara, 2017; Saboori \& Sulaiman, 2013; Shahbaz et al., 2019; Stern, 2004).

Moreover, the FDI factor also has a controversial discussion in the relationship to the environment because it not only could bring better environmental quality but also cause costly negative externalities for the host countries. There are two hypotheses explaining the above 
results: the pollution haven and the pollution halo hypothesis. In the pollution haven hypothesis, the polluting industries tend to move to the lessened countries in environmental protection regulations; therefore, the more FDI attracted, the more environmental degradation is (Kearsley $\&$ Riddel, 2010). In contrast, those countries attracting green FDI often follow the pollution halo hypothesis, which means that FDI has contributed to a better environment for the host countries. This is because foreign companies use better management practices and advanced technology (Zarsky, 1999; Zhu, Duan, Guo, \& Yu, 2016). According to Hoang and Duong (2018), FDI is essential for economic development in Vietnam by attracting capital, enhancing firm-level efficiency. It's also the main factor in transferring cutting-edge technology and encouraging innovation in the Fourth Industrial Revolution in Vietnam.

On the other hand, there is a close relationship between $\mathrm{CO}_{2}$ emissions and energy consumption. The non-renewable energy consumption has often given out the positive effect of increasing $\mathrm{CO}_{2}$ emission (Kasman \& Duman, 2015; Shahbaz, Mahalik, Shah, \& Sato, 2016). However, studies on renewable energy consumption have shown the possibility of decreasing $\mathrm{CO}_{2}$ emissions (Dogan \& Seker, 2016; Dong, Sun, Jiang, \& Zeng, 2018; Saudi, Sinaga, \& Jabarullah, 2019). According to Saudi et al. (2019), thanks to energy efficiency and green energy, energy consumption would not damage the environment but will contribute to sustainable development.

Based on this literature review, the elements of economic and energy factors will be input into the models to reveal their roles in the effort of controlling $\mathrm{CO}_{2}$ emissions. The results of this paper will help us indirectly evaluate the effectiveness of policies to reduce $\mathrm{CO} 2$ emissions in Vietnam from 1985 to 2018.

\section{Methodology and data}

\subsection{Data and research model}

The study reviewed the data of $\mathrm{CO}_{2}$ emissions $\left(\mathrm{CO}_{2}{ }^{1}\right)$, annual foreign direct investment $\left(\mathrm{FDI}^{2}\right)$, annual gross domestic product per capita $\left(\mathrm{GDP}^{3}\right)$, energy consumption from oil $\left(\mathrm{OIL}^{4}\right)$, total non-renewable energy consumption, which includes oil, gas energy, and coal (NONRE $\left.{ }^{5}\right)$ and hydro-power renewable energy consumption $\left(\mathrm{RE}^{6}\right)$ in Vietnam. The data were chosen from 1985 to 2018 because all the variables in this study are increasing rapidly in this period. The dependent variable $\mathrm{CO}_{2}$ emission is taken from Knoema and measured in per capita emissions. The independent variables consist of GDP and FDI, are collected from United Nations Conference on Trade and Development, expressed in current US\$; OIL, NONRE, and RE, which are from the project of Our World in Data, at Global Change Data Lab of Oxford university, measured in terawatt-hours (TWh) per year.

The aim of our study is focused on analyzing the effects of economic growth and energy consumption on $\mathrm{CO}_{2}$ emissions in the short-term and long-term. Besides, the study also tests whether renewable energy will be important in reducing $\mathrm{CO}_{2}$ emission while there is an existence of FDI. According to Prime Minister (2016) on the decision of National Power Development Master Plan for 2011 - 2020 with the vision to 2030, the nation has to reduce the share of coal-fired energy while given more investment in the oil industry and renewable-energy

\footnotetext{
${ }^{1}$ Annual $\mathrm{CO}_{2}$ emissions per capita (Unit: metric tons per capita).

${ }^{2}$ Foreign direct investment (Unit: US dollar at current price in million).

${ }^{3}$ Annual gross domestic product per capita (Unit: US dollar at current and constant (2010) price).

${ }^{4}$ Energy consumption from oil (Unit: terawatt-hours (TWh)).

${ }^{5}$ Total non - renewable energy consumption: oil, gas and coal (Unit: terawatt-hours (TWh)).

${ }^{6}$ Hydro-power renewable energy consumption (Unit: terawatt-hours (TWh)).
} 
(Phan, Nguyen, \& Nguyen, 2020). Therefore, we developed the two models with the difference in sources of non-renewable energy consumption (as Equations $1 \& 2$ below) to test the assumption that the shift in energy policies will be better for the environment. We transformed all variables to their natural logarithmic forms to achieve consistent empirical evidence. The models are presented as follows:

$$
\begin{aligned}
& \ln C O_{2 t}=\beta_{0}+\beta_{1} \ln G D P_{t}+\beta_{2} \ln F D I_{t}+\beta_{3} \ln O I L_{t}+\beta_{4} \ln R E_{t}+\varepsilon_{t} \\
& \ln C O_{2 t}=\beta_{0}+\beta_{1} \ln G D P_{t}+\beta_{2} \ln F D I_{t}+\beta_{3} \ln N O N R E_{t}+\beta_{4} \ln R E_{t}+\varepsilon_{t}
\end{aligned}
$$

(Model 1)

(Model 2)

Where $\mathrm{t}$ and $\varepsilon$ denote time and error.

\subsection{ARDL estimation}

In order to test the role of renewable, non-renewable energy consumption, the study applied the Autoregressive Distributed Lag (ARDL) method. According to Pesaran, Shin, and Smith (2001), ARDL solved the problem that time series variables which integrated in a different order, except for variables are stationary in levels two (I(2)) and above. Thus, many studies have used the ARDL method, and same for the current study (Bölük \& Mert, 2015).

Two functions are proposed for the study by ARDL approach as follows:

$$
\begin{aligned}
& \ln C O_{2 t}=\beta_{0}+\sum_{t=i}^{p} \beta_{1} \ln C O_{2 t-i}+\sum_{t=i}^{p} \beta_{2} \ln G D P_{t-i}+\sum_{t=i}^{p} \beta_{3} \ln F D I_{t-i}+\sum_{t=i}^{p} \beta_{4} \ln O I L_{t-i}+\sum_{t=i}^{p} \beta_{5} \ln R E_{t-i}+\varepsilon_{t} \\
& \ln C O_{2 t}=\beta_{0}+\sum_{t=i}^{p} \beta_{1} \ln C O_{2 t-i}+\sum_{t=i}^{p} \beta_{2} \ln G D P_{t-i}+\sum_{t=i}^{p} \beta_{3} \ln F D I_{t-i}+\sum_{t=i}^{p} \beta_{4} \ln N O N R E_{t-i}+\sum_{t=i}^{p} \beta_{5} \ln R E_{t-i}+\varepsilon_{t}
\end{aligned}
$$

If $\mathrm{CO}_{2}$, GDP, and FDI have a long-term connection with sources of energy consumption which are presented with the indication in this study. Hence, by utilizing the below equation, we calculate the beta value of the short-run coefficients:

$$
\begin{aligned}
& \Delta \ln C O_{2 t}=\beta_{0}+\sum_{t=i}^{p} \beta_{1} \Delta \ln C O_{2 t-i}+\sum_{t=i}^{p} \beta_{2} \Delta \ln G D P_{t-i}+\sum_{t=i}^{p} \beta_{3} \Delta \ln F D I_{t-i}+\sum_{t=i}^{p} \beta_{4} \Delta \ln O I L_{t-i}+\sum_{t=i}^{p} \beta_{5} \Delta \ln R E_{t-i}+\theta E C T_{t-1}+\varepsilon_{t} \\
& \Delta \ln C O_{2 t}=\beta_{0}+\sum_{t=i}^{p} \beta_{1} \Delta \ln C O_{2 t-i}+\sum_{t=i}^{p} \beta_{2} \Delta \ln G D P_{t-i}+\sum_{t=i}^{p} \beta_{3} \Delta \ln F D I_{t-i}+\sum_{t=i}^{p} \beta_{4} \Delta \ln N O N R E_{t-i}+\sum_{t=i}^{p} \beta_{5} \Delta \ln R E_{t-i}+\theta E C T_{t-1}+\varepsilon_{t}
\end{aligned}
$$

The coefficient of the ERROR-CORRECTION TERM (ECT) measures the adjustment speed of the variables back to the long run equilibrium (Nkoro \& Uko, 2016). The coefficient of ECT is expected to be negative and statistically significant.

\section{Results}

\subsection{Descriptive statistics and unit root tests}

The data were chosen from 1985 to 2018 because, in this period, Vietnam has implemented economic reform and transited to a market economy, led to significant changes. Therefore, the country has achieved great growth of wealth, trade, and investment as well as $\mathrm{CO}_{2}$ emissions. The descriptive statistics of all variables are shown in Table 1 and Figure 1 in the period of $1985-2018$. 


\section{Table 1}

Descriptive statistics

\begin{tabular}{|l|c|c|c|c|c|c|}
\hline Variables & $\begin{array}{c}\mathbf{C O}_{2} \\
\text { (metric tons } \\
\text { per capita) }\end{array}$ & $\begin{array}{c}\text { US dollar at current } \\
\text { and constant (2010) } \\
\text { price }\end{array}$ & $\begin{array}{c}\text { FDI } \\
\text { US dollar at } \\
\text { current price in } \\
\text { million }\end{array}$ & $\begin{array}{c}\text { OIL } \\
\text { (terawatt- } \\
\text { hours) }\end{array}$ & $\begin{array}{c}\text { NONRE } \\
\text { (terawatt- } \\
\text { hours) }\end{array}$ & $\begin{array}{c}\text { RE } \\
\text { (terawatt- } \\
\text { hours) }\end{array}$ \\
\hline Mean & 1.0593 & $811,111.93$ & $34,554.42$ & $124,335.1$ & 274,855 & $24,112.1$ \\
\hline Std.Dev. & 0.7474 & $782,335.3$ & $41,606.92$ & $81,957.3$ & $220,853.8$ & $22,458.4$ \\
\hline Min & 0.2870 & $78,774.3$ & 40,791 & $23,436.7$ & $56,389.8$ & 1,384 \\
\hline Max & 2.81 & $2,558.956$ & $144,991.3$ & $289,018.9$ & $784,088.4$ & $80,706.2$ \\
\hline
\end{tabular}

Source: The researcher's data analysis

Generally, Vietnam has achieved more than 811USD gross domestic product per capita, attracted 34,554.42USD annual foreign direct investment. This country used on average 124TWh oil energy, 24.1121TWh renewable energy consumption, and 274.855TWh nonrenewable energy consumption, including oil, natural gas energy, and coal energy per year. Consequently, more than 1.0593 metric tons of carbon per capita are emitted into the environment. Referred to Figure 1, all variables as $\mathrm{CO}_{2}$, FDI, GDP, OIL, NONRE, and RE are soaring in the study period.

Figure 1 presents the trends of the six-time series, highlighting the tendency toward rising of all the variables over the 1985 - 2018 period. The author used the unit root tests to determine if trending data should be first differenced or regressed on deterministic functions of time to make the data stationary. If these variables are I(0) or I(1), then ARDL techniques can be used to model these long run relations (Pesaran et al., 2001). The Dickey-Fuller test was applied to test the null hypothesis that a unit root is present in a time series data. Table 2 showed the results of the Unit Root test by Augmented Dickey Fuller (ADF). The result concluded that all the variables are stationary at the 1st difference in time series from 1985 to 2018.
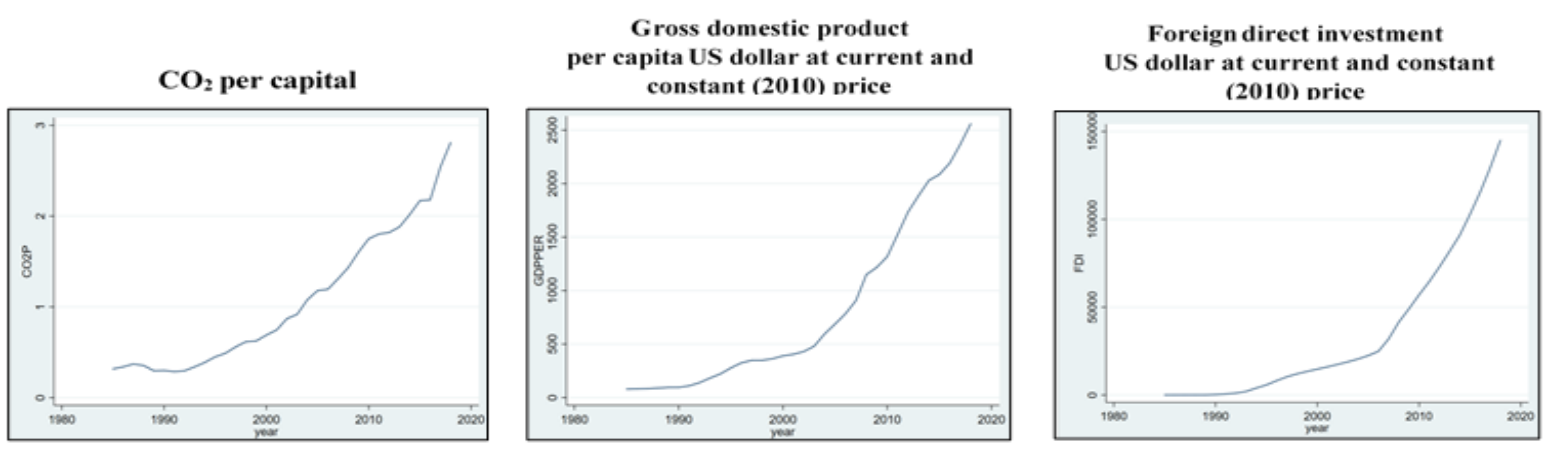

Oil energy

Renewable energy consumption

Nonrenewable energy consumption
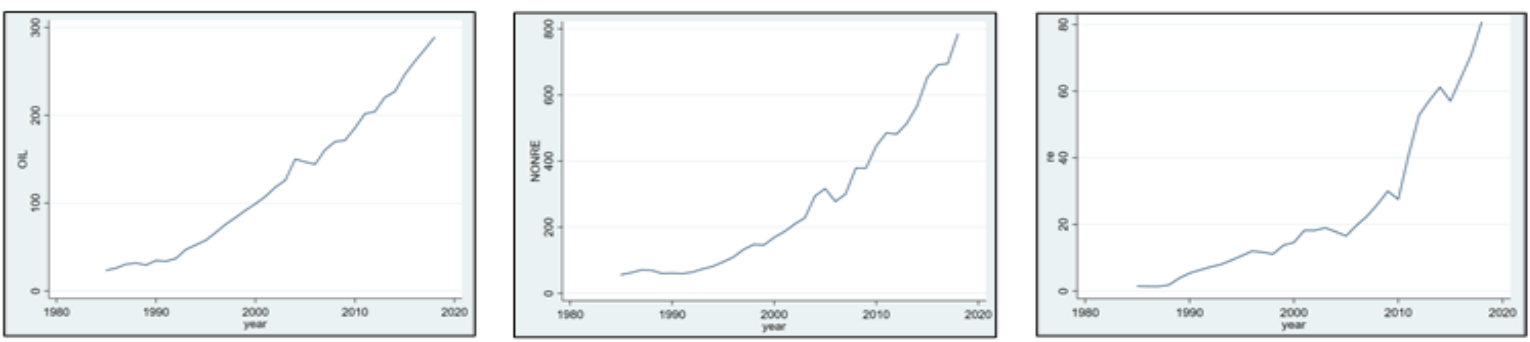

Figure 1. Time trends of the considered variables

Note: NONRE is for oil, natural gas and coal energy, RE is for hydropower renewable energy consumption 
Thus, ARDL bound test (Pesaran et al., 2001) is used for empirical analysis. It provides better results than multivariate cointegration approaches in the case of small sample properties. This test of cointegration can be used regardless of the stationarity level of the underlying variables whether they are I(0), I(1) or a combination of both.

Table 2

Unit root tests results

\begin{tabular}{|l|c|c|}
\hline \multicolumn{1}{|c|}{ Variables } & ADF Test & Order of integration \\
\hline $\ln \mathrm{CO}_{2}$ & $-3.900^{* * *}$ & $\mathrm{I}(1)$ \\
\hline $\ln \mathrm{GDP}$ & $-3.346^{* *}$ & $\mathrm{I}(1)$ \\
\hline $\operatorname{lnFDI}$ & $-2.902 *$ & $\mathrm{I}(1)$ \\
\hline $\ln \mathrm{OIL}$ & $-6.106^{* * *}$ & $\mathrm{I}(1)$ \\
\hline $\ln \mathrm{NONRE}$ & $-4.992 * * *$ & $\mathrm{I}(1)$ \\
\hline $\ln \mathrm{RE}$ & $-4.106^{* * *}$ & $\mathrm{I}(1)$ \\
\hline
\end{tabular}

Note: *: significant at $10 \%$; **: significant at $5 \%$; ***: significant at $1 \%$

Source: Data analysis result of the researcher

\section{Table 3}

ARDL bound test results

\begin{tabular}{|c|c|c|c|c|c|}
\hline \multicolumn{5}{|c|}{ Dependent variable: $\operatorname{lnCO}_{2}$} \\
\hline \multicolumn{3}{|c|}{$\begin{array}{c}\text { Linear model with OIL and RE } \\
\text { (Model 1) }\end{array}$} & \multicolumn{3}{c|}{$\begin{array}{c}\text { Linear model with NONRE and RE } \\
\text { (Model 2) }\end{array}$} \\
\hline \multicolumn{3}{|c|}{ F value = 17,930 } & \multicolumn{3}{c|}{ F value = 4.721 } \\
\hline Prob. & Lower Limit I(0) & Upper Limit I(1) & Prob. & Lower Limit I(0) & Upper Limit I(1) \\
\hline $1 \%$ & 3.74 & 5.06 & $1 \%$ & 3.74 & 5.06 \\
\hline $5 \%$ & 2.86 & 4.01 & $5 \%$ & 2.86 & 4.01 \\
\hline $10 \%$ & 2.45 & 3.52 & $10 \%$ & 2.45 & 3.52 \\
\hline
\end{tabular}

Source: Data analysis result of the researcher

According to the results in Table 3, for $1 \%$ confidence intervals, the calculated F statistic of value in Model 2 is 4.721, higher than the lower-bound critical value (3.74). While Model 1 has an F statistic value is 17,930 , which is higher than the upper-bound critical value (5.06) at the $1 \%$ level. It concludes that there is a long-term cointegration relationship between the independent variables GDP, FDI, OIL, NONRE, RE, and the dependent variable $\boldsymbol{C O}_{2}$. This result also shows that the $\mathrm{CO}_{2}$ emissions in the two models have been effected by all the independent variables in the long-term.

\subsection{ARDL long-run and short-run results}

The ARDL long-run and short-run estimates are presented in Table 4. ADJ in the result, which shows the Error Correction Term, has significant with the correct sign at the 5\% level (for Model 1) and at the $1 \%$ level (for Model 2), supporting the evidence of a stable long run relationship among the variables. The coefficients in the 02 models are respectively -1.5542 (Model 1) and -3.0412 (Model 2), suggesting that a deviation from the long run equilibrium level of $\mathrm{CO}_{2}$ emissions in one year is corrected by $155.42 \%$ and $304.12 \%$ over the following year. 
The models have the Durbin-Watson d statistic, which is in turn of 2.3483 (Model 1) and 2.4896 (Model 2), which are far from the center of its distribution $(\mathrm{d}=3)$. Therefore, this study doesn't contain auto-correlation. Besides that, Ramsey RESET test (Regression SpecificationError Test) is used to look for either omitted variables or functional form misspecification in this study. Using a significant p-value of 0.05 , the RESET test in 2 models is not significant, indicating there are no omitted variables bias problems in diagnostics tests.

Table 4

Long-run and short-run carbon functions

\begin{tabular}{|c|c|c|c|c|c|}
\hline \multicolumn{6}{|c|}{ Dependent variable: $\operatorname{lnCO} 2$} \\
\hline \multicolumn{3}{|c|}{ Linear model with OIL and RE (Model 1) } & \multicolumn{3}{|c|}{$\begin{array}{c}\text { Linear model with NONRE and RE } \\
\text { (Model 2) }\end{array}$} \\
\hline Variables & Coefficient & P-value & Variables & Coefficient & P-value \\
\hline ADJ & $-1.5542^{* *}$ & 0.029 & ADJ & $-3.0412^{* * * *}$ & 0.009 \\
\hline \multicolumn{6}{|c|}{ Long-run coefficient estimates } \\
\hline $\operatorname{lnGDP}$ & $0.3305^{* *}$ & 0.011 & $\operatorname{lnGDP}$ & -0.0195 & 0.857 \\
\hline $\operatorname{lnFDI}$ & $-0.1661^{* * *}$ & 0.000 & $\operatorname{lnFDI}$ & $0.0276^{* *}$ & 0.030 \\
\hline $\operatorname{lnOIL}$ & $1.2977^{* * * *}$ & 0.001 & lnNONRE & $1.0159^{* * * *}$ & 0.000 \\
\hline $\operatorname{lnRE}$ & $-0.1705^{* *}$ & 0.044 & $\ln \mathrm{RE}$ & $-0.1553^{* * * *}$ & 0.002 \\
\hline \multicolumn{6}{|c|}{ Short-run coefficient estimates } \\
\hline$\Delta \operatorname{lnGDP}(1)$ & $-0.5472^{*}$ & 0.070 & $\Delta \operatorname{lnGDP}(4)$ & $0.8859^{* *}$ & 0.019 \\
\hline$\Delta \operatorname{lnFDI}(2)$ & $0.2198^{*}$ & 0.068 & $\Delta \operatorname{lnFDI}(1)$ & $-0.1458^{*}$ & 0.057 \\
\hline$\Delta \operatorname{lnOIL}(1)$ & -0.9342 & 0.201 & $\Delta \operatorname{lnNONRE1}(2)$ & $-1.5358^{* *}$ & 0.007 \\
\hline$\Delta \operatorname{lnRE}(2)$ & $0.3749^{* *}$ & 0.029 & $\Delta \operatorname{lnRE}(2)$ & $0.5454^{* *}$ & 0.011 \\
\hline Constant & $-9.8688^{* *}$ & 0.024 & Constant & $-16.2881^{* * *}$ & 0.009 \\
\hline $\mathbf{R}^{2}$ & 0.9309 & & $\mathbf{R}^{2}$ & 0.9633 & \\
\hline Adj - $\mathbf{R}^{2}$ & 0.7138 & & Adj - $R^{2}$ & 0.8481 & \\
\hline \multicolumn{6}{|c|}{ Diagnostic test statistics } \\
\hline Durbin-Watson test & 2.3483 & & Durbin-Watson test & 2.4896 & \\
\hline Ramsey-RESET test & 0.96 & 0.4941 & Ramsey-RESET test & 2.49 & 0.1996 \\
\hline
\end{tabular}

Note: *: significant at $10 \%$; **: significant at $5 \%$; **: significant at $1 \%$

Source: The researcher's data analysis

As shown in Table 4, in the long run, there are differences on the effects of two economic factors. In Model 1, which is based on oil as non-renewable energy, GDP is to increase $\mathrm{CO}_{2}$ emission (Dinh \& Lin, 2014; Shahbaz et al., 2019) while in Model 2 (total energy as coal, oil, and gas as non-renewable energy) shows no effect (statistically non-significant). The factor FDI helps to decrease $\mathrm{CO}_{2}$ emission in Model 1 and create a very small positive effect on $\mathrm{CO}_{2}$ emission in Model $2\left(\beta_{\text {lnFDI }}=0.027\right)$. That means in the growth model based on oil consumption, Vietnam has followed the pollution halo hypothesis, and FDI shows its role in decoupling economic growth and the environment (Dinh \& Lin, 2014). This result implied the sign of the initial success of economic policies to attract eco-investment to develop green production. Therefore, we should have more stringent regulations to select the FDI that comes into the country to transition towards a low carbon economy. 
For energy consumption, the result is the same as other studies, non -renewable energy is significant to contribute to $\mathrm{CO}_{2}$ emission in both models while renewable energy let decrease the emissions (Jebli, Youssef, \& Ozturk, 2015a; Dogan \& Seker, 2016; Dong et al., 2018; Saudi et al., 2019).

To check the stability of the ARDL model, we applied the CUSUMsq tests recommended by Brown, Durbin, and Evans (1975) to examine the constancy of the parameters. This test is based on an established target mean and a reliable value for sigma. The results in Figure 2 of Model 1 and 2 are between the upper and lower critical bounds at the 5\% significance level, confirming the stability of the ARDL estimates.
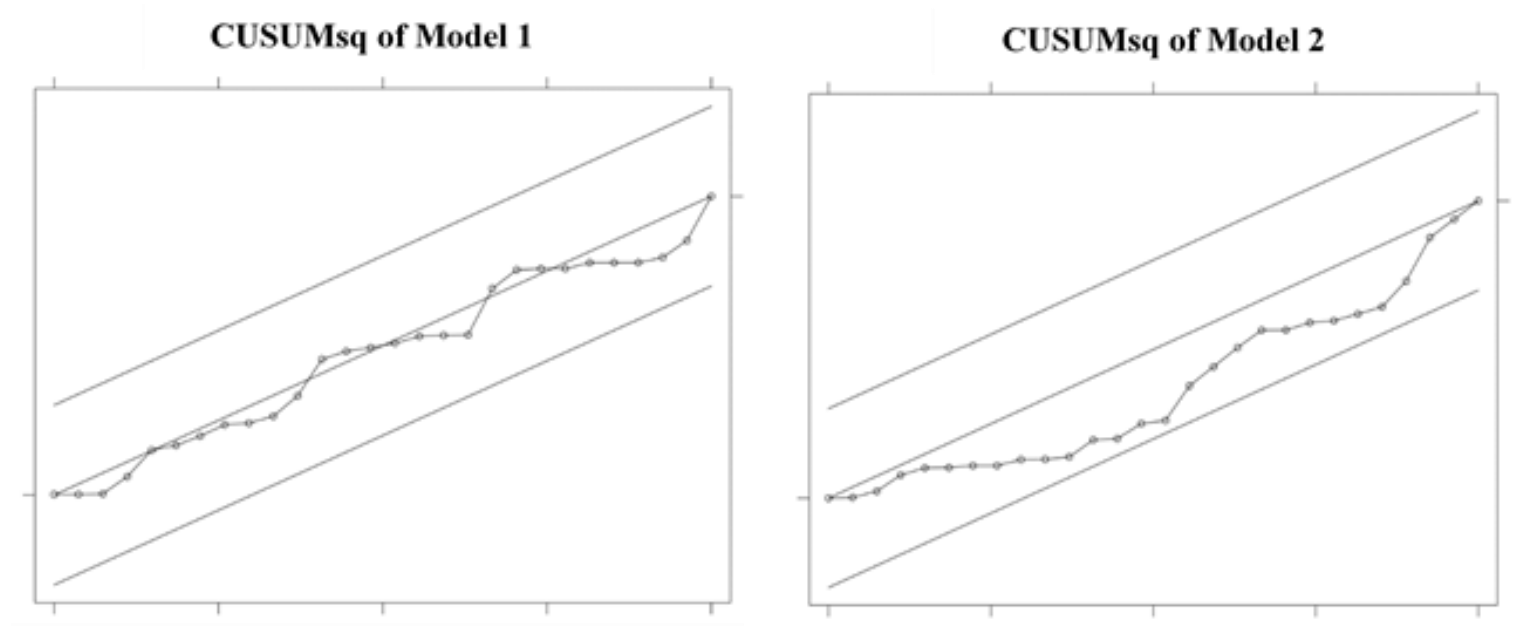

Figure 2. Plot cumulative sum of the squares of Model 1 and Model 2

\section{Discussion and conclusion}

This study has indirectly evaluated the effectiveness of Vietnamese policies' response to climate change by investigating the relationship between economic, energy consumption factors and environmental degradation in Vietnam. The determinants of this study are economical and energy as GDP, FDI, and sources of energy consumption. The two models have been developed by the same economic factors but differentiation energy consumption sources between oil, renewable energy, and non-renewable \& renewable energy. Our results reveal that the policies response to climate changes on the shift of energy consumption from coal-fired power to oil and renewable energy have been truly meaningful for the environment with the results of the negative effect of FDI on $\mathrm{CO}_{2}$ emissions. In the long run, though GDP has caused an increase of emissions, FDI is a significant and different effect in the two models. In the oil \& renewable energy model, FDI has a significant negative effect on the emission while the other is vice versa. That implies the initial success of the policies' response to climate change. Economic growth could be an essential solution for environmental sustainability in Vietnam, though it currently relies on FDI only. It suggests the co-existence of economic growth and environment when Vietnam follows the policies on attracting and selecting quality, eco-investment to pursue sustainable development.

On the other hand, the energy consumption factors are both significant and have the same effect on the environment in the long run. The consumption of oil and non-renewable energy has a positive effect and caused an increase of pollutants while renewable energy is negative. That confirms the good impact of green energy in the battle of reducing $\mathrm{CO}_{2}$ emissions. Therefore, to achieve sustainable development, Vietnam should have put more investment in renewable energy from not only the government but also the private sector in various sources of renewable energy. 
Moreover, the government needs to give more incentives to change customer's preferences to environmentally friendly products and promote green lifestyles and sustainable consumption.

\section{References}

Apergis, N. (2016). Environmental Kuznets curves: New evidence on both panel and countrylevel $\mathrm{CO}_{2}$ emissions. Energy Economics, 54(C), 263-271. doi:10.1016/j.eneco.2015.12.007

Audinet, P. S., Singh, B., Kexel, D. T., Suphachalasai, S., Makumbe, P., \& Mayer, K. (2016). Exploring a low-carbon development path for Vietnam. Retrieved October 10, 2020, from The World Bank website: http://documents.worldbank.org/curated/en/ 773061467995893930/Exploring-a-low-carbon-development-path-for-Vietnam

Beckerman, W. (1992). Economic growth and the environment: Whose growth? Whose environment? World Development, 20(4), 481-496. doi:10.1016/0305-750X(92)90038-W

Bölük, G., \& Mert, M. (2015). The renewable energy, growth and environmental Kuznets curve in Turkey: An ARDL approach. Renewable and Sustainable Energy Reviews, 52(C), 587595. doi:10.1016/j.rser.2015.07.138

Brown, R. L., Durbin, J., \& Evans, J. M. (1975). Techniques for testing the constancy of regression relationships over time. Journal of the Royal Statistical Society. Series B (Methodological), 37(2), 149-192.

Dinda, S., \& Coondoo, D. (2006). Income and emission: A panel data-based cointegration analysis. Ecological Economics, 57(2), 167-181. doi:10.1016/j.ecolecon.2005.03.028

Dinh, L. H., \& Lin, S. M. (2014). $\mathrm{CO}_{2}$ emissions, energy consumption, economic growth and FDI in Vietnam. Managing Global Transitions, 12(3), 219-232.

Dogan, E., \& Seker, F. (2016). Determinants of $\mathrm{CO}_{2}$ emissions in the European Union: The role of renewable and non-renewable energy. Renewable Energy, 94(C), 429-439. doi:10.1016/j.renene.2016.03.078

Dong, K., Sun, R., Jiang, H., \& Zeng, X. (2018). $\mathrm{CO}_{2}$ emissions, economic growth, and the environmental Kuznets curve in China: What roles can nuclear energy and renewable energy play? Journal of Cleaner Production, 196, 51-63. doi:10.1016/j.jclepro.2018.05.271

Hoang, C. Q., \& Duong, C. T. (2018). Analysis of foreign direct investment and economic growth in Vietnam. International Journal of Business, Economics and Law, 15(5), 9-28.

Iwata, H., Okada, K., \& Samreth, S. (2012). Empirical study on the determinants of $\mathrm{CO}_{2}$ emissions: Evidence from OECD countries. Applied Economics, 44(27), 3513-3519. doi:10.1080/00036846.2011.577023

Jebli, M. B., Youssef, S. B., \& Ozturk, I. (2015a). The role of renewable energy consumption and trade: Environmental Kuznets curve analysis for Sub-Saharan Africa countries. African Development Review, 27(3), 288-300. doi:10.1111/1467-8268.12147

Kasman, A., \& Duman, Y. S. (2015). $\mathrm{CO}_{2}$ emissions, economic growth, energy consumption, trade and urbanization in new EU member and candidate countries: A panel data analysis. Economic Modelling, 44(C), 97-103. doi:10.1016/j.econmod.2014.10.022

Kearsley, A., \& Riddel, M. (2010). A further inquiry into the pollution haven hypothesis and the environmental Kuznets curve. Ecological Economics, 69(4), 905-919. doi:10.1016/j.ecolecon.2009.11.014 
Kuznets, S. (1955). Economic growth and income inequality. The American Economic Review, 45(1), 1-28.

Mrabet, Z., \& Alsamara, M. (2017). Testing the Kuznets curve hypothesis for Qatar: A comparison between carbon dioxide and ecological footprint. Renewable and Sustainable Energy Reviews, 70(C), 1366-1375. doi:10.1016/j.rser.2016.12.039

Nasir, M., \& Ur Rehman, F. (2011). Environmental Kuznets curve for carbon emissions in Pakistan: An empirical investigation. Energy Policy, 39(3), 1857-1864. doi:10.1016/j.enpol.2011.01.025

Nguyen, N. H. (2014). Policies for environmentally sustainable development: Perspectives from Vietnam. In J. Huang \& S. Gupta (Eds.), Environmental Policies in Asia (pp. 57-72). Singapore: World Scientific Publishing.

Nkoro, E., \& Uko, A. K. (2016). Autoregressive Distributed Lag (ARDL) cointegration technique: Application and interpretation. Journal of Statistical and Econometric Methods, 5(4), 63-91.

Ozturk, I., \& Acaravci, A. (2013). The long-run and causal analysis of energy, growth, openness and financial development on carbon emissions in Turkey. Energy Economics, 36(C), 262267. doi:10.1016/j.eneco.2012.08.025

Pesaran, M. H., Shin, Y., \& Smith, R. J. (2001). Bounds testing approaches to the analysis of level relationships. Journal of Applied Econometrics, 16(3), 289-326.

Phan, A., Nguyen, N. T. K., \& Nguyen, H. T. T. (2020). Vietnam's national energy development strategy to 2030 and Outlook to 2045. International Journal of Economics and Business Administration, VIII(4), 1023-1032. doi:10.35808/ijeba/647

Prime Minister. (2012). Decision on the approval of the national green growth strategy. Hanoi, Vietnam: Socialist Republic of Vietnam.

Prime Minister. (2016). Quyết định của Thủ tuoóng Chính Phủ số 428/QĐ-TTg vào ngày 18 tháng 03 năm 2016 về Phê duyệt điều chinh quy hoạch phát triển điện lực quốc gia giai đoạn 2011-2020 có xét đến năm 2030 [Decision of the Prime Minister No. 428/QD-TTg of 2016 on the Approval of the revised national power development master plan for the 2011 2020 period with the vision to 2030]. Retrieved October 15, 2020, from https://thuvienphapluat.vn/van-ban/Thuong-mai/Quyet-dinh-428-QD-TTg-de-an-dieuchinh-quy-hoach-phat-trien-dien-luc-quoc-gia-2011-2020-2030-2016-306608.aspx

Saboori, B., \& Sulaiman, J. (2013). $\mathrm{CO}_{2}$ emissions, energy consumption and economic growth in Association of Southeast Asian Nations (ASEAN) countries: A cointegration approach. Energy, 55(C), 813-822. doi:10.1016/j.energy.2013.04.038

Saboori, B., Sapri, M., \& bin Baba, M. (2014). Economic growth, energy consumption and $\mathrm{CO}_{2}$ emissions in OECD (Organization for Economic Co-operation and Development)'s transport sector: A fully modified bi-directional relationship approach. Energy, 66(C), 150161. doi:10.1016/j.energy.2013.12.048

Saudi, M. H. M., Sinaga, O., \& Jabarullah, N. H. (2019). The role of renewable, non-renewable energy consumption and technology innovation in testing environmental Kuznets curve in Malaysia. International Journal of Energy Economics and Policy, 9(1), 299-307. doi:10.32479/ijeep.7295 
Shafik, N., \& Bandyopadhyay, S. (1992). Economic growth and environmental quality: Time series and cross-country evidence. Retrieved October 18, 2020, from https://documents.worldbank.org/en/publication/documents-reports/documentdetail /833431468739515725/economic-growth-and-environmental-quality-time-series-andcross-country-evidence

Shahbaz, M., Haouas, I., \& Hoang, V. T. H. (2019). Economic growth and environmental degradation in Vietnam: Is the environmental Kuznets curve a complete picture? Emerging Markets Review, 38(C), 197-218. doi:10.1016/j.ememar.2018.12.006

Shahbaz, M., Mahalik, M. K., Shah, S. H., \& Sato, J. R. (2016). Time-varying analysis of $\mathrm{CO}_{2}$ emissions, energy consumption, and economic growth nexus: Statistical experience in next 11 countries. Energy Policy, 98(C), 33-48. doi:10.1016/j.enpol.2016.08.011

Stern, D. I. (2004). The rise and fall of the environmental Kuznets curve. World Development, 32(8), 1419-1439. doi:10.1016/j.worlddev.2004.03.004

UNEP. (2011). Towards a green economy: Pathways to sustainable development and poverty eradication. Retrieved October 20, 2020, from https://sustainabledevelopment.un.org/ index.php? page $=$ view $\&$ type $=400 \& n r=126 \&$ menu $=35$

Van Phong Chinh Phu (VPCP). (2019). Đánh giá Chiến lược tăng trưởng xanh [Green growth strategy assessment]. Retrieved October 22, 2020, from http://vpcp.chinhphu.vn/Home/ Danh-gia-Chien-luoc-tang-truong-xanh/20197/26244.vgp

Woetzel, J., Pinner, D., Samandari, H., Engel, H., Krishnan, M., Boland, B., \& Powis, C. (2020). Climate risk and response: Physical hazards and socioeconomic impacts. Retrieved October 12, 2020, from https://www.mckinsey.com/business-functions/sustainability/ourinsights/climate-risk-and-response-physical-hazards-and-socioeconomic-impacts

World Bank. (1993). World development report 1992: Development and the environment. Retrieved October 25, 2020, from World Bank Group website: http://documents.worldbank.org/ curated/en/995041468323374213/World-developmentreport-1992-development-and-the-environment

Zarsky, L. (1999). Havens, halos and spaghetti: Untangling the evidence about foreign direct investment and the environment. Paper presented at the OECD Conference on Foreign Direct Investment and the Environment, The Hague.

Zhu, H., Duan, L., Guo, Y., \& Yu, K. (2016). The effects of FDI, economic growth and energy consumption on carbon emissions in ASEAN-5: Evidence from panel quantile regression. Economic Modelling, 58(C), 237-248. doi:10.1016/j.econmod.2016.05.003

Zimmer, A., Jakob, M., \& Steckel, J. C. (2015). What motivates Vietnam to strive for a low-carbon economy? On the drivers of climate policy in a developing country. Energy for Sustainable Development, 24, 19-32. doi:10.1016/j.esd.2014.10.003

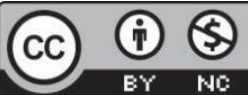

Creative Commons Attribution-NonCommercial 4.0 International License. 